\title{
Physics Outreach to Improve the Conceptual Application Skills for High School Students
}

\author{
Finda Hadiatin Afifah ${ }^{1}$, Dwi Sulisworo ${ }^{2, *}$, Suparwoto ${ }^{1}$, Moh Toifur ${ }^{1}$ \\ ${ }^{1}$ Department of Master of Physics Education, Universitas Ahmad Dahlan, Indonesia \\ ${ }^{2}$ Department of Master of Physics Education, Universitas Negeri Yogyakarta, Indonesia
}

Received September 3, 2019; Revised September 27, 2019; Accepted October 5, 2019

Copyright $\odot 2019$ by authors, all rights reserved. Authors agree that this article remains permanently open access under the terms of the Creative Commons Attribution License 4.0 International License

\begin{abstract}
Physics outreach is one of the exciting media for learning the phenomena. Many sophisticated tools are developed and used in various purposes both in the form of virtual-based equipment, computing, and simulation designed to build a sense of interest in physical phenomena. These expensive tools are not available for a rural school. This study is to utilize simple physics outreach to encourage student learning interest. There are many opportunities in applying physics outreach using materials collected from the around of school. This research is quasi-experimental research with pretest and posttest one group design. The objective of this research is to find out the influence of the outreach program to the conceptual application skills. The learning media for outreach activities include Heron' fountain, Lift of the wing, and mosquito's spray. Pretest and posttest were measured using the essay problems. These problems were arranged for higher-order thinking skills of Bloom taxonomy. The statistical technique of analysis the result was paired sample T-test (two-tailed, alpha $=0.05$ ). Based on this study, there is a significant improvement on the conceptual application skill after the student was taught using this media. The main factor of this increase was fun activities during learning.
\end{abstract}

Keywords Physics Outreach, Learning Interest, Learning Innovation, Rural Area, High School

\section{Introduction}

In today's learning, various efforts are made to grow a variety of new skills needed to solve complex problems. Competencies expected in the learning process experience changes compared to learning in the previous era. Issues about critical thinking, collaboration, communication, and creativity are essential issues in learning. Learning strategies based on ICT develop rapidly to accommodate the millennial generation. However, the problem of science learning related to interest in science and understanding of science concepts and principles is still relatively high felt by educators.

In the field of science learning, many researchers and educators conduct research and application of various methods or strategies in learning to achieve these competencies, one of which is by conducting physics outreach. The strategy of implementing the program outreach is carried out at various levels of education from the level of primary education to higher education. Some findings indicate that by implementing outreach, participants become increased in their awareness and knowledge [1]; motivation for and proficiency in science [2, $3]$; interest in science $[4,5]$. These results indicate that outreach activities provide a positive learning environment for students in science learning.

Outreach Physics is a term used in school activities or research institutions that aims to understand audience insights and awareness in the field of physics. The center of Physical outreach is generally on developing, providing learning resources, and providing participants with a variety of arranging ideas for other participants. In this era, educators give many efforts to create the application of Physics Outreach involving students in the process of integrating various phenomena in everyday life. The aim of this application is not only to push physics education out of traditional one but also to attract students on building their new perspectives on physical phenomena.

Some research shows that these learning strategies are to increase critical thinking skills, primarily through problem-solving activities [6]. The used problems in learning are obtained from various phenomena encountered in everyday life as a non-routine problem [7]. This simplification physics is a school learning activity in support of physical outreach that can encourage learning that is interesting and supports the improvement of 
students' thinking skills $[4,8]$. However, searches are related to the application of many outreach concepts that use sophisticated and expensive research tools. These sophisticated tools are developed and used in various purposes both in the form of virtual-based equipment, computing, and simulation designed to build a sense of interest in physical phenomena [9-12].

This situation is undoubtedly a plan in schools in border areas that do not have sufficient resources. As an alternative, it is necessary to develop various equipment that will be used in physical outreach using materials that are cheap and readily available in the school environment. With these tools, activities in physical outreach need to accommodate various variations that can be made by students who can explain the solutions to the complexities of physics. In schools with expensive facilities, the development of a variety of simple learning tools with the principle of physics is one alternative in the learning process.

There are many opportunities in applying physics outreach using materials collected from the around of school. Therefore, the purpose of this study is to develop and implement physics outreach to improve critical thinking skills in secondary school students. This development initiative is essential to consider more needs in physics teachers who are more scientifically literate. These new ways of learning will enable better public appreciation of the potential of science in helping real problems in everyday life.

\section{Methods}

\subsection{Research Context}

This research is quasi-experimental research with pretest and posttest controlled group design. The objective of this research is to find out the influence of the outreach program to the conceptual application skills. The population covered five classes of eleventh-grade student. The sample consists of two groups. The student in the first group (22 students) was taught using physics outreach learning. The other group was taught using face-to-face learning as the controlled group (29 students). The independent variable is the physics learning strategy using outreach concept. The dependent variable is the conceptual application skills. This variable was measured after all students had finished their learning activity for five sessions (90 minutes per session; 2 times per week).

\subsection{Statistical Analysis}

There are three stages of statistical analysis applied. The first is comparing the two groups before learning. From the results of the measurement of the conceptual application skills before learning, a one-way ANOVA was performed to find out if there were differences in the mean of the pretest scores. If there were no significant difference, then the two groups would be used as a group to compare results after learning. The second is comparing the mean of the posttest to find out the effect of learning strategies on the results of the posttest (conceptual application skills). The technique is one way ANOVA. The third is to analyze a significant score increase from pretest to posttest in the treatment group (which was taught with the physics outreach approach). The analysis technique used is a paired T-test.

\subsection{Instrument}

The learning media for outreach activities include Heron' fountain, Lift of the wing, and mosquito's spray (see Figure 1 to 3). This media supported the Dynamics Fluid lesson for eleventh-grade students in Magetan Regency, East Java Province, Indonesia (a rural school).

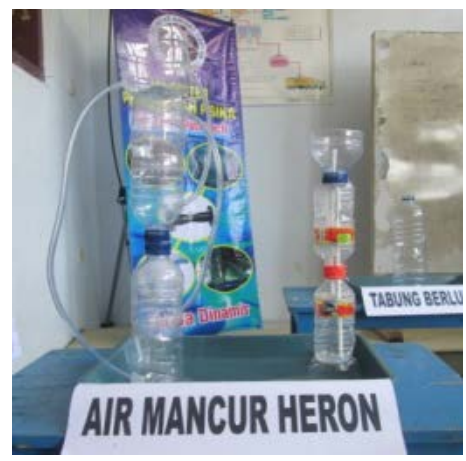

Figure 1. Heron's fountain

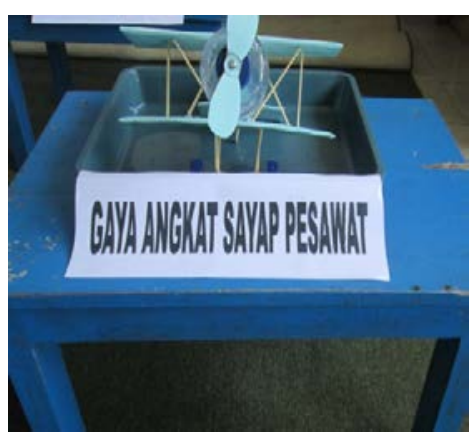

Figure 2. Lift force of the wing

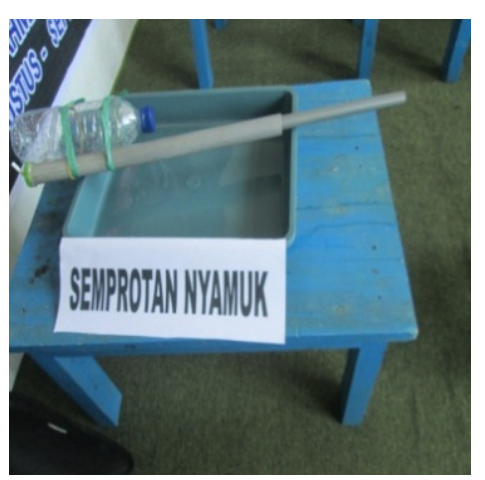

Figure 3. Mosquito’s spray 
Students experimented using the particular worksheet to apply the physics concept. They also explored the phenomena of this experiment to improve conceptual understanding.

Pretest and posttest were measured using the essay problems. These problems were arranged for higher-order thinking skills of Bloom taxonomy. The number of problems is ten items. This problem has been analyzed related to the item validity, the difficulty index, the power of discrimination. The score criteria included identification of the problem, interpretations of data or information, determination of strategy, application of the approach, and reflection or justification. The score of each criterion is from 1 to 5 . The example of the essay problem is shown in Fig. 4.

9. Perhatikan gambar berikut ini!

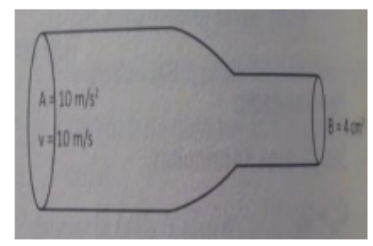

Jika luas penampang pipa $\mathrm{A}=$

$10 \mathrm{~cm}^{2}$ dan pipa $\mathrm{B}=4 \mathrm{~cm}^{2}$.

Kecepatan aliran air pada pipa

B, jika kecepatan aliran air pada

pipa $A=10 \mathrm{~m} / \mathrm{s}$, adalah $\ldots(\mathrm{m} / \mathrm{s})$

Figure 4. The simple example of the Ventury tube problem. The area of A tube is $10 \mathrm{~cm} 2$, and one of tube $B$ is $4 \mathrm{~cm} 2$. The water of velocity at the A tube is $10 \mathrm{~m} / \mathrm{s}$. Determine the water of velocity at the B tube. The flow is from left to right in the horizontal position

\subsection{Learning Activities}

For the physics outreach activity, the teacher arranged the particular room to be set up. The room has been designed for outreach activities. In this room, students experimented following the provided guidelines. This activity is carried out in groups. Worksheets provide scientific steps that can encourage students to higher-order thinking. At the end of the activity, each student gives an interpretation of this physics outreach-based learning experience. In this way, students can understand the concept of dynamic fluid and gain real experience during their experiments.

\section{Result and Discussion}

The quality of education in Indonesia, especially in the rural area need to be improved [13]. The limitation of the learning facilities, especially in physics learning, becomes one of the constraints for student skill improvement.
Teacher in this school is still using conventional learning, face-to-face learning, in the classroom for almost all learning subject. As consequences, the student's skills in the concept application in physics subject is low. The understanding of the basic concept in physics is essential $[14,15]$; unfortunately, many students fail to understand and to apply these concepts.

One of the alternative solutions is developing and applying physics outreach to increase the conceptual application skills of students [1,9]. The application of concepts is action taken to help to identify an object and to learn something new [9]. Physics outreach is an activity in the field of education, focusing on broadening the audience and physics application, especially in the villages [9]. Physics outreach could be training, introduction to experiment tools related to physics, science libraries, or museums. Besides delivering services, outreach has an educational role in raising the awareness of the existing services.

\subsection{Pretest Score Comparison of Two Groups}

Comparison of the mean of the pretest score in the two groups is used to determine the students' initial ability in the application of concept skills before giving treatment (See Table 1).

Table 1. The descriptive of pretest score

\begin{tabular}{|c|c|c|c|c|c|}
\hline Groups & N & Mean & $\begin{array}{c}\text { Std. } \\
\text { Deviation }\end{array}$ & Min. & Max. \\
\hline Physics Outreach & 22 & 31.227 & 4.6592 & 21.00 & 40.00 \\
\hline $\begin{array}{c}\text { Face-to-face } \\
\text { Learning }\end{array}$ & 29 & 32.035 & 3.5905 & 27.00 & 38.00 \\
\hline Total & 51 & 31.686 & 4.0620 & 21.00 & 40.00 \\
\hline
\end{tabular}

From Table 1, the mean score of conceptual application skills before learning in the control group $(32,035)$ is slightly higher than the treatment group $(21,227)$. From the standard deviation values, students in the class who will obtain learning with physics outreach tend to have more significant variation (4.66) than classes that use a face-to-face approach (3.59). The results of homogeneity analysis with Levene's value model show that both groups are homogeneous (p-value $=0.299$ ).

Table 2 shows the analysis with one-way ANOVA to find out whether the mean pretest scores of the two groups differed significantly.

Table 2. One-way ANOVA of the pretest score

\begin{tabular}{|c|c|c|c|c|c|}
\hline & $\begin{array}{c}\text { Sum of } \\
\text { Squares }\end{array}$ & df & $\begin{array}{c}\text { Mean } \\
\text { Square }\end{array}$ & F & Sig. \\
\hline Between Groups & 8.151 & 1 & 8.151 & .489 & .488 \\
\hline Within Groups & 816.829 & 49 & 16.670 & & \\
\hline Total & 824.980 & 50 & & & \\
\hline
\end{tabular}


The p-value is 0.488 , which is higher than the alpha $(0.05)$. These results indicate that the mean of pretest between the two groups did not differ significantly. The next step is to find out the differences in the results of the posttest in the two groups.

\subsection{Posttest Score Comparison of Two Groups}

After learning, students had been measured their conceptual application skills according to the instrument that had been developed. Table 3 shows the descriptive statistical results.

Table 3. The descriptive of posttest score

\begin{tabular}{|c|c|c|c|c|c|}
\hline Groups & N & Mean & $\begin{array}{c}\text { Std. } \\
\text { Deviation }\end{array}$ & Min. & Max. \\
\hline $\begin{array}{c}\text { Physics } \\
\text { Outreach }\end{array}$ & 22 & 41.682 & 5.1398 & 31.00 & 51.00 \\
\hline $\begin{array}{c}\text { Face-to-face } \\
\text { Learning }\end{array}$ & 29 & 34.621 & 3.3850 & 30.00 & 40.00 \\
\hline Total & 51 & 37.667 & 5.4760 & 30.00 & 51.00 \\
\hline
\end{tabular}

From Table 3, the average score of the application of concept skills after learning in the control group $(34,621)$ is lower than the treatment group $(41,682)$. From the standard deviation values, students in the class who have obtained learning with physics outreach tend to have more considerable variation (5.14) than classes that use a face-to-face approach (3.38).

Next, a one-way ANOVA was applied to the posttest score to determine the effect of the learning strategy. Table 4 shows the results of this analysis.

Table 4. One-way ANOVA of the posttest score

\begin{tabular}{|c|c|c|c|c|c|}
\hline & $\begin{array}{c}\text { Sum of } \\
\text { Squares }\end{array}$ & df & $\begin{array}{c}\text { Mean } \\
\text { Square }\end{array}$ & F & Sig. \\
Between Groups & 623.733 & 1 & 623.733 & 34.905 & .000 \\
\hline Within Groups & 875.600 & 49 & 17.869 & & \\
\hline Total & 1499.333 & 50 & & & \\
\hline
\end{tabular}

From Table 4, the p-value is less than 0.05 , which means there is a significant difference between the average posttest score of the treatment group and the control group. In other words, there is an influence of learning strategies on conceptual application skills.

Refer to Table 3; it implies that students who obtain learning with physics outreach have a better physics conceptual application skill than students who learn face-to-face. It is necessary to look at whether there is a significant improvement in the conceptual application skills to students learning with physics outreach to find out the effectiveness of these results.

\subsection{Pretest and Posttest Score Comparison of the Treatment Group}

The skill improvement in conceptual applying is found by comparing the mean of pretest and posttest. The technique used is a paired T-test. Table 5 shows the results of measuring the concept application skills at the before learning (Pre Test) and after learning (Post Test).

Table 5. Paired Samples Statistics

\begin{tabular}{|c|c|c|c|c|}
\hline Pair $\mathbf{1}$ & Mean & $\mathbf{N}$ & Std. Deviation & Std. Error Mean \\
\hline Pre Test & 31.227 & 22 & 4.6592 & .9933 \\
\hline Post Test & 41.682 & 22 & 5.1398 & 1.0958 \\
\hline
\end{tabular}

Table 5 shows that the mean of posttest score (41.68) is higher than the mean of pretest score (31.23). This score shows there is an increase in students' skills after participating in physics outreach activities. However, there is a tendency for the distribution of skills to spread after learning. It can be analyzed from the value of the standard deviation. This phenomenon is represented in the standard deviation of the posttest score (5.14) higher than the standard deviation of the pretest score (4.66).

Table 6 shows the correlation between the pretest and posttest scores. This table is used to find out whether there is a relationship between the skill of applying concepts before following the physics outreach and after following it.

Table 6. Paired Samples Correlations

\begin{tabular}{|c|c|c|c|}
\hline Pair 1 & N & Correlation & Sig. \\
\hline Pre Test \& Post Test & 22 & .932 & .000 \\
\hline
\end{tabular}

From Table 6, the p-value is 0.00 (smaller than 0.05). This result indicates that there is a significant correlation between the two scores, where the correlation value is 0.932 .

The results of the analysis by paired-sample T-test was used to find out the effect of the application of learning models on the concept application. Table 7 shows this result. This table shows whether the mean of Pre Test and Post Test scores differ significantly.

Table 7. Paired Samples Test

\begin{tabular}{|c|c|c|c|c|c|c|}
\hline Pair 1 & Mean & $\begin{array}{c}\text { Std. } \\
\text { Deviation }\end{array}$ & $\begin{array}{c}\text { Std. } \\
\text { Error } \\
\text { Mean }\end{array}$ & t & df & $\begin{array}{c}\text { Sig. } \\
\text { (2-tailed) }\end{array}$ \\
\hline $\begin{array}{c}\text { Pre Test } \\
\text {-Post } \\
\text { Test }\end{array}$ & -10.454 & 1.870 & .398 & -26.219 & 21 & .000 \\
\hline
\end{tabular}

Table 7 shows that the p-value or Sig. is 0.00 (2-tailed), which is smaller than 0.05 . This result indicates that the average pretest and posttest scores are significantly different. In other words, there is an influence of the application of the learning model on the concept application skills.

From these results, it shows that physics outreach provides various opportunities in learning innovation that is more enjoyable for students. Students' higher interest in everyday science problems becomes a motivator to learn 
more deeply in various concepts of physics as a part of the daily solution.

During the learning process in groups learning with physics outreach, researchers make observations on aspects of interest, activity, and collaboration. This result can be an explanation for why this strategy can improve the conceptual application skills.

The basic idea of physics outreach is to build awareness, knowledge, skills in physics through a variety of exciting activities [2, 3]. This concept is indeed relatively too broad and can have various meanings following the interests of learning. In the learning model applied in this study, physics outreach is more focused on the use of various simple learning resources in the school environment to be able to understand contextual physics phenomena. The cases taken are everyday phenomena which contain various physical concepts simultaneously. The ability of students to understand these concepts and explain their interrelationships becomes an alternative to gain a deeper understanding of physics concepts $[16,17]$.

During the learning process, students in groups created their various equipment (Heron's fountain, lift force of the wing, and mosquito's spray). During this process, they were encouraged to discuss, seek understanding of the concept of dynamic fluid, and explain the mechanism of action of the tool. During this activity, students would be motivated to be more active in work and study. They learned not only in physics but also in the skill of making tools and making sure they work well. This way of learning is intended not only to master the material but also to encourage understanding of physical phenomena from the perspective of students [4, 9].

Variation of activities is one of the essential keys in the application of physics outreach. In this study, various types of tools had been provided that explain various physical phenomena. These variations could be learned by students freely and do not have to be sequential sequentially. With this approach, students learned from the phenomena that were most interesting to them.

With the development of information and communication technology, the opportunity for the development of physics outreach integrated with technology is possible. Physical phenomena can be monitored, recorded, and transferred digitally for further analysis. Physical phenomena may originate from various events experienced in daily life. This method is a new opportunity for increasing the application of the concept of physics outreach. We may use various sensors embedded in smartphones [18, 19, physics simulation applications [20], physics phenomenon analysis applications [21] to develop better physics outreach implementation.

\section{Conclusions}

Physics outreach media is developed using materials that can be obtained around the school and from used materials, especially plastic bottles. The application of physics outreach can improve student skills in applying physics concepts. A critical factor affected on improving this ability is a higher sense of interest when students attend physics outreach activities. More in-depth observations of several other factors such as motivation, understanding of concepts, can be an alternative to further study related to physics outreach.

\section{Acknowledgements}

This research is funded by the Ministry of Research, Technology, and Higher Education of Republic Indonesia under Postgraduate Research Grant for the year 2019.

\section{REFERENCES}

[1] S. Allen, P. B. Campbell, L. D. Dierking, B. N. Flagg, A. J. Friedman, C. Garibay, D. A. Ucko. Framework for evaluating impacts of informal science education projects, In Report from a National Science Foundation Workshop. The National Science Foundation, Division of Research on Learning in Formal and Informal Settings, February 2008.

[2] T. M. Swift, S. E. Watkins. An Engineering Primer for Outreach to K-4 Education, Journal of STEM Education, Institute for STEM Education and Research, Jan 2004.

[3] J. Vennix, P. Den Brok, R. Taconis. Perceptions of STEM-based outreach learning activities in secondary education,” Learning Environments Research, Vol. 20, No. 1, 21-46, 2017.

[4] A. T. Jeffers, A. G. Safferman, S. I. Safferman. Understanding $\mathrm{K}-12$ engineering outreach programs, Journal of professional issues in engineering education and practice, Vol. 130, Vo. 2, 95-108. 2004.

[5] D. Milgram. How to recruit women and girls to the science, technology, engineering, and math (STEM) classroom, Technology and engineering teacher, Vol. 71, No. 3, 4, 2011.

[6] S. A. Rodzalan, M. M. Saat. The perception of critical thinking and problem solving skill among Malaysian undergraduate students, Procedia-Social and Behavioral Sciences, Vol. 172, 725-732, 2015.

[7] M. Öztürk, Y. Akkan, A. Kaplan. Reading comprehension, Mathematics self-efficacy perception, and Mathematics attitude as correlates of students' non-routine Mathematics problem-solving skills in Turkey, International Journal of Mathematical Education in Science and Technology, 1-17, 2019.

[8] A. Tiwari, P. Lai, M. So, K. Yuen. A comparison of the effects of problem based learning and lecturing on the development of students' critical thinking, Medical education, Vol. 40, No. 6, 547-554, 2006.

[9] S. Laursen, C. Liston, H. Thiry, J. Graf. What good is a 
scientist in the classroom? Participant outcomes and program design features for a short-duration science outreach intervention in $\mathrm{K}-12$ classrooms, CBE-Life Sciences Education, Vol. 6, No. 1, 49-64, 2007.

[10] I. D. Rahmawati, Suparmi, W. Sunarno. Students Concept Understanding of Static Fluid Based on the Types of Teaching, International Conference on Mathematics, Science, and Education. Conf. Series, Vol. 983, 012029, 2018.

[11] A. Shishigu, A. Hailu, Z. Anibo, Problem Based Learning and Conceptual Understanding of College Female Students in Physics, Eurasia Journal of Mathematics, Science and Technology Education, Vol. 14, No. 1, 145-154, 2018.

[12] A. Jacob. Investigating the Conceptual Understanding of Physics through an Interactive Lecture-Engagement, Cumhuriyet International Journal of Education-CIJE, Vol. 6, No. 1, 82-96, 2017.

[13] D. Sulisworo. The Contribution of the Education System Quality to Improve the Nation's Competitiveness of Indonesia, Journal of Education and Learning, Vol. 10, No. 2, pp. 127-138, 2016.

[14] G. Gunawan, G., N. Nisrina, N. M. Y. Suranti, L. Herayanti, \& R. Rahmatiah, "Virtual Laboratory to Improve Students' Conceptual Understanding in Physics Learning,” Journal of Physics: Conference Series (Vol. 1108, No. 1, p. 012049). IOP Publishing, November 2018.

[15] I. M. Greca, \& A. R. P. de Ataíde, "The influence of epistemic views about the relationship between physics and mathematics in understanding physics concepts and problem solving,” Key Competences in Physics Teaching and Learning (pp. 55-64). Springer, Cham, 2017.

[16] U. Usmeldi, “The Development of Research-based Physics Learning Model with Scientific Approach to Develop Students' Scientific Processing Skill,” Jurnal Pendidikan IPA Indonesia, Vol 5, No. 1, 134-139, 2016.

[17] G. J. Hwang, L. Y. Chiu, C. H. Chen, “A contextual game-based learning approach to improving students' inquiry-based learning performance in social studies courses,” Computers \& Education, Vol. 81, 13-25, 2015.

[18] M. A. González, M. A. González, M. E. Martín, C. Llamas, O. Martínez, J. Vegas, ... C. Hernández, “Teaching and learning physics with smartphones. In Blended Learning: Concepts, Methodologies, Tools, and Applications” (pp. 866-885). IGI Global, 2017.

[19] K. Hochberg, J. Kuhn, A. Müller, "Using smartphones as experimental tools-effects on interest, curiosity, and learning in physics education," Journal of Science Education and Technology, Vol. 27, No. 5, 385-403, 2018.

[20] A. Price, C. Wieman, K. Perkins, "Teaching With Simulations,” The Science Teacher, Vol. 86, No. 7, 46-52, 2019.

[21] M. H. Ramli, K. T. Chan, W. F. Yap, "Study of simple pendulum using Tracker video analysis and high speed camera: an interactive approach to analyze oscillatory motion," Solid State Science and Technology, Vol. 24, 297-305, 2016. 